\title{
Effect of Some Different Sourses of Organic Fertilizers and Seaweed Extract on Growth and Essential Oil of Sweet Fennel (Foeniculum vulgare Mill.) Plants. Eisa, E. A. \\ Medicinal and Aromatic Research Department, Hort. Res. Inst.,Agric. Res.Center, Giza, Egypt.
}

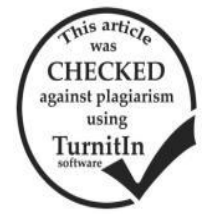

\section{ABSTRACT}

This work was carried out during the two successive winter seasons of 2014/ 2015 and 2015/ 2016 at Meet Assas village, (Private Farm) Gharbieh Governorate, Egypt, on sweet fennel plants, to investigate the utilization of some different sources and rates of organic manure (chicken and farmyard manure) at 50 and100\% of recommended rate / fed., foliar fertilizer of seaweed extracts ( without and with $2 \mathrm{~g} /$ liter) compared with mineral NPK fertilizer at 50 and $100 \%$ of recommended rate /fed., and their interaction on plant growth, yield (bulb and fruit fennel) and chemical composition. The application of farmyard manure at $100 \%$ with seaweed extract showed increased growth compared to the chicken manure at $100 \%$ or inorganic fertilizer at $100 \%$ with seaweed extracts in the plant fresh and dry weight, plant height, number of leaves, bulb and fruits yield, as well as essential oil. Similarly, chemical parameters have also shown increased from farmyard manure over the inorganic fertilizers. Thus our study provides the evidence for using seaweed extract with organic fertilizer like farmyard manure by farmers to have better yield to produce from bulbs and fruits, organic manure is easy available, environmentally safe and cost effective in sweet fennel plants

\section{INTRODUTION}

Sweet Fennel (Foeniculum vulgare Mill.) is a plant belonging to the Umbelliferae (Apiaceae) family; it is native to North Africa, Mediterranean Region, southern Europe and Asia (Abd El- Wahab and Mehasen, 2009). Medicinal and aromatic plants are important economic products which represent significant sources of economic revenue and foreign exchange and are among the most important agricultural export products. The Egyptian government in collaboration with the WHO seeks to protect fennel plants that serve as a source for pharmaceutical compounds and who might increase the export of these plants from Egypt to all over the world (Egypt Magazine, 2000). Fennel is traditionally used as a remedy for upper respiratory catarrh due to its calming effects on bronchitis and cough. It is also used as a diuretic and often added to purgatives to alleviate their tendency to cause gripe and improve their flavor (Grieve, 1984). It is also used to promote lactation, aid to weight loss and longevity (Facciola, 1990). Fennel oil showed bactericidal and antifungal properties. The flavor of fennel oil depends upon its main constitutes: fenchone, estragole and anethole. Eestragole is a bitter tasting element, while anethole has a sweet anise-like flavor (Braun and Franz, 1990). Proportions of these ingredients vary according to strains and region (Lawrence, 1984).

Application of inorganic fertilizer for promoting the growth of important staple food crops has been used for many decades. But synthetic manure adversely affected the soil chemistry thus soil become less affable for plant growth, in addition to it become also harmful for human health (Camargo and Alonso 2006). Organic products based on concept of increasing market opportunity exclude or prohibit the use of conventional crop inputs common to modern farming. Chemical pesticides and fertilizers are not allowed in organic certification program (Abd-Alla et. al, 2001). To achieve optimal quality and economic returns, organic farming system rely upon crop rotation, crop residues, animal manures, legumes, green manures, off farm organic wastes and biological pest control (Abd-Alla et $a l, 2001)$.These components maintain soil productivity, supply nutrients and help control insects, weeds, and other pests. Pollution with chemical fertilizers arose as an aim of health cure, thus attempts were done for solving problems of chemical fertilization, and the organic farming technique represents a move towards an alternative system of agriculture (Abd-Alla et al, 2001).Recently seaweeds gaining more importance as the growth stimulator, seaweeds are natural growth stimulator which enhance of plant growth at various level of plants life (Fleurence, 1999). Use of seaweed extract in organic farming technique is one of the safest ways to conserve environmental resources, avoid pollution and obtain food and agriculture crops. Seaweeds are organic and biodegradable in nature (Cassan, et al.,1992). Seaweed extracts have proven to accelerate the health and growth of plants. Seaweed extracts supplies nitrogen, phosphorous, potash as well as trace minerals like $\mathrm{Zn}, \mathrm{Mn}, \mathrm{Mg}$, Fe, etc(Crouch et al., 1990). Its extract contains natural plant growth substances like auxins, gibberlins and cytokinins (Crouch and Van Staden, 1993). This trace elements present in seaweed extract are in naturally chelated form and are readily available to plants. It accelerates photosynthesis and further develops healthy foliage (Kavitha et al., 2008). It is essential to explore the extent of applicability of seaweeds extract in organic farming techniques. Hence, in present investigation possibilities were explored to study the effect of foliar applications of seaweed extract and organic fertilizers on growth, bulb fruit yield, volatile oil and quality improvement of sweet fennel plant

\section{MATERIALS AND METHODS}

Field experiments were carried out in aprivate farm at Meet Assas village, Gharbieh Governorate, Egypt, during the two successive winter growing seasons of 2014/ 2015 and 2015/ 2016 to investigate the utilization of some different sources and rates of organic manure (chicken and farmyard manure) and foliar fertilization treatments with seaweed extracts, 
compared with mineral NPK fertilizer and their interaction on plant growth, yield (bulb and fruit fennel), chemical composition and quality of sweet fennel plant. Seeds of sweet Fennel plants were obtained from the Medicinal and Aromatic Plants Section of Agricultural Research Center, El-Dokki, Cairo, Egypt.

Some physical and chemical properties of the experimental soil at the depth of 0-30 $\mathrm{cm}$ were shown in Table (A).According Page et al. (1982).Chemical analyses of organic manure were cleaned in Table (B). Chemical analyses of organic manure were determinate by using stander methods as described by A.O.A.C. (1990).

The Field experiment section to split-plot design factorial experiment in complete randomized block design with 3 replicates. The main-plot was divided into plots, and the plot area was $1.5 \times 3$ meters, containing five rows, every row was 1.5 meters, and the seed sown was in hill on distance $25 \mathrm{~cm}$ between hills and the distance between two rows was $60 \mathrm{~cm}$. in both seasons. The main-plots were devoted for organic and inorganic fertilizers, while the seaweed extract treatments randomly distributed in the sub-plot. The experimental studied treatments were as follows:

\section{A-Mineral NPK fertilizers rates:}

Mineral fertilizers were added at 50 and $100 \%$ of recommended rate as follows:

1-Mineral nitrogen fertilizer was added as ammonium sulfate $(21.5 \% \mathrm{~N})$ at the two rates 30 and $60 \mathrm{~kg}$ $\mathrm{N} /$ fed.

2-Mineral phosphate fertilizer was added as curium super phosphate $\left(15.5 \% \mathrm{P}_{2} \mathrm{O}_{5}\right)$ at the two rates 22.5 and $45 \mathrm{~kg} \mathrm{P}_{2} \mathrm{O}_{5} /$ fed.
3-Mineral potassium fertilizer was added as potassium sulfate at 25 and $50 \mathrm{~kg} \mathrm{~K}_{2} \mathrm{O} / \mathrm{fed}$.

Only half dose of nitrogen and potassium were after month from sowing, after thinned to one plant per hill (before the first irrigation), and while the remaining portion was applied four weeks after (before the third irrigation) as well as, the calcium superphosphate was added during the preparation of soil.

\section{B- organic manure fertilizers:}

Organic fertilizers were added at 50 and $100 \%$ of recommended rate as follows:

1-Farmyard manure (FYM) was added at 20and $40 \mathrm{~m}^{3}$ /fed.

2-Chicken manure (CHM) was added at 15 and $30 \mathrm{~m}^{3}$ /fed. soil.

Organic manure was added before ploughed the

\section{C- Seaweed extract}

Seaweed extract was used as foliar spraying (2 $\mathrm{g} / \mathrm{L}$ ) at three times at four, six and eight weeks after seed sowing date. Seaweed extract (Algifret) were prepared as powder of Ascophyllum nodosum and biological fertilizer, contains appreciable quantities of macro nutrients $\left(\mathrm{N} 1 \%, \mathrm{P}_{2} \mathrm{O}_{5} 3 \%, \mathrm{~K}_{2} \mathrm{O} 18 \%, \mathrm{~S} 1.5 \%\right.$ $\mathrm{Mg} 0.3 \%$ and $\mathrm{Ca} 0.1 \%$ ), micro nutrients (B 110 ppm, $\mathrm{Fe} 150 \mathrm{ppm}, \mathrm{Mn} 10 \mathrm{ppm} \mathrm{Cu} 4 \mathrm{ppm}$ and $\mathrm{Zn} 50$ ppm), phytohormones, amino acids and vitamins. It was obtained from Sidase Egypt Company. All agricultural practices were conducted according to the main recommendations by the Egyptian Ministry of Agriculture.

Table (A):Somephysical and chemical properties of experimental soil in two seasons of 2014-215 and 20152016.

\begin{tabular}{|c|c|c|c|c|c|c|c|c|c|c|c|}
\hline \multirow{2}{*}{ Season } & \multirow{2}{*}{$\begin{array}{c}\text { Clay } \\
\%\end{array}$} & \multirow{2}{*}{$\begin{array}{c}\text { Silt } \\
\%\end{array}$} & \multirow{2}{*}{$\begin{array}{c}\text { Sand } \\
\%\end{array}$} & \multirow{2}{*}{$\begin{array}{c}\text { Organic } \\
\text { Matter\% }\end{array}$} & \multirow{2}{*}{$\mathbf{P H}$} & \multicolumn{6}{|c|}{ Available nutrients (ppm) } \\
\hline & & & & & & $\mathbf{N}$ & $\mathbf{P}$ & $\mathbf{K}$ & $\mathbf{Z n}$ & $\mathbf{F e}$ & Mn \\
\hline Fir: & 45.5 & 30.2 & 24.3 & 2.15 & 8.1 & 50.4 & 13.5 & 381 & 1.45 & 8.21 & 12.1 \\
\hline Second & 45.7 & 30.1 & 24.2 & 2.19 & 8.0 & 51.2 & 14.1 & 394 & 1.38 & 7.81 & 12.4 \\
\hline
\end{tabular}

Table (B): Some physical and chemical properties of different organic fertilizers used in two seasons of 2014215 and 2015-2016.

\begin{tabular}{|c|c|c|c|c|c|c|c|c|c|c|}
\hline \multirow{2}{*}{ Season } & \multirow{2}{*}{$\mathbf{p H}$} & \multirow{2}{*}{$\mathrm{EC} \mathrm{dS/m}$} & \multirow{2}{*}{$\begin{array}{c}\mathrm{C}: \mathrm{N} \\
\text { ratio\% }\end{array}$} & \multicolumn{3}{|c|}{ Macro-elements (\%) } & \multicolumn{4}{|c|}{ Micro-elements (ppm) } \\
\hline & & & & $\mathbf{N}$ & $\mathbf{P}$ & $\mathbf{K}$ & $\mathbf{F e}$ & Mn & $\mathbf{Z n}$ & $\mathbf{C U}$ \\
\hline \multicolumn{11}{|l|}{ Farmyard manure } \\
\hline $2014 / 2015$ & 7.0 & 4.1 & 20.1 & 1.15 & 0.51 & 0.87 & 546 & 112 & 165 & 35 \\
\hline $2015 / 2016$ & 7.1 & 4.2 & 19.5 & 1.14 & 0.53 & 0.85 & 562 & 115 & 158 & 32 \\
\hline \multicolumn{11}{|l|}{ Chicken manure } \\
\hline $2014 / 2015$ & 8.1 & 6.2 & 21.6 & 1.19 & 0.68 & 1.11 & 415 & 174 & 215 & 41 \\
\hline $2015 / 2016$ & 8.0 & 6.1 & 22.3 & 1.18 & 0.71 & 1.13 & 412 & 183 & 231 & 40 \\
\hline
\end{tabular}

\section{Data recorded:}

A random sample of four plants was taken from each experimental treatment four month after sowing and the following data were recorded during the two seasons.

1-Vegetative growth characters: Plant height $(\mathrm{cm})$; leaf number per plant; bulb dimensions (length, width and thickness); leaves, bulbs and total plant fresh and dry weight (g/plant) and bulb yield (ton / feddan). Chlorophyll $\mathrm{a}+\mathrm{b}$ were using calorimetrically in the sweet fennel leaves during two seasons according to the methods described by Wettstein(1957) and calculated as $\mathrm{mg} / \mathrm{g}$ fresh weight.

2- fruit yield: At harvesting stage, samples of four plants were randomly chosen from each experimental unit for determining the following characters i.e. number of umbels/plantandfruit yield ( $\mathrm{g} /$ plant and ton / feddan)

3- Chemical composition:Samples were dried in an electric oven at $70{ }^{\circ} \mathrm{C}$ for 24 hours, then, dried herb 
samples was used to determine total carbohydrate percentages according to Herbert et al. (1971). Then, $\mathrm{N}, \mathrm{P}$ and $\mathrm{K}$ were determined according to A.O.A.C (1990)

Statistical analysis:-The data of the experiment was tabulated and subjected to statistical analysis according to Snedecor and Cochran (1980).

\section{RESULTS AND DISCUSSION}

I-Effect of mineral, organic fertilizers and seaweed extract on vegetative growth:

1-Plant length and Leaves numbers / plant:

Data in Table (1) show that organic or mineral fertilizers (NPK) at full dose (100\%) had significant effect on plant height and leaves number / plant compared to half dose $(50 \%)$, in both seasons. The farmyard manure at full dose treatment gave the highest values, followed by NPK fertilizers then chicken manure in the two seasons. These results are in agreement with those reported by Sanni (2016) on Amaranthus hybridus plant pointed out that the highest values of plant height, leaves number / plant obtained with cow dung fertilizer compared with NPK fertilizer.

Concerning seaweed extract treatments, plants sprayed with seaweed extract significantly increased plant height and number of leaves / plant of sweet fennel in the two season compared to control(without seaweed extract ) as shown in Table (1), Confirm these results Shehata et al. (2011) mentioned that seaweed extract was the best in enhancing leaf height, number of leaves /plant on celeriac plant .

Table (1): Effect of some different sources of organic fertilizer and seaweed extract on plant heightand number of leaves numbers / plantof sweet fennel plant during 2014-2015 and 2015-2016 seasons.

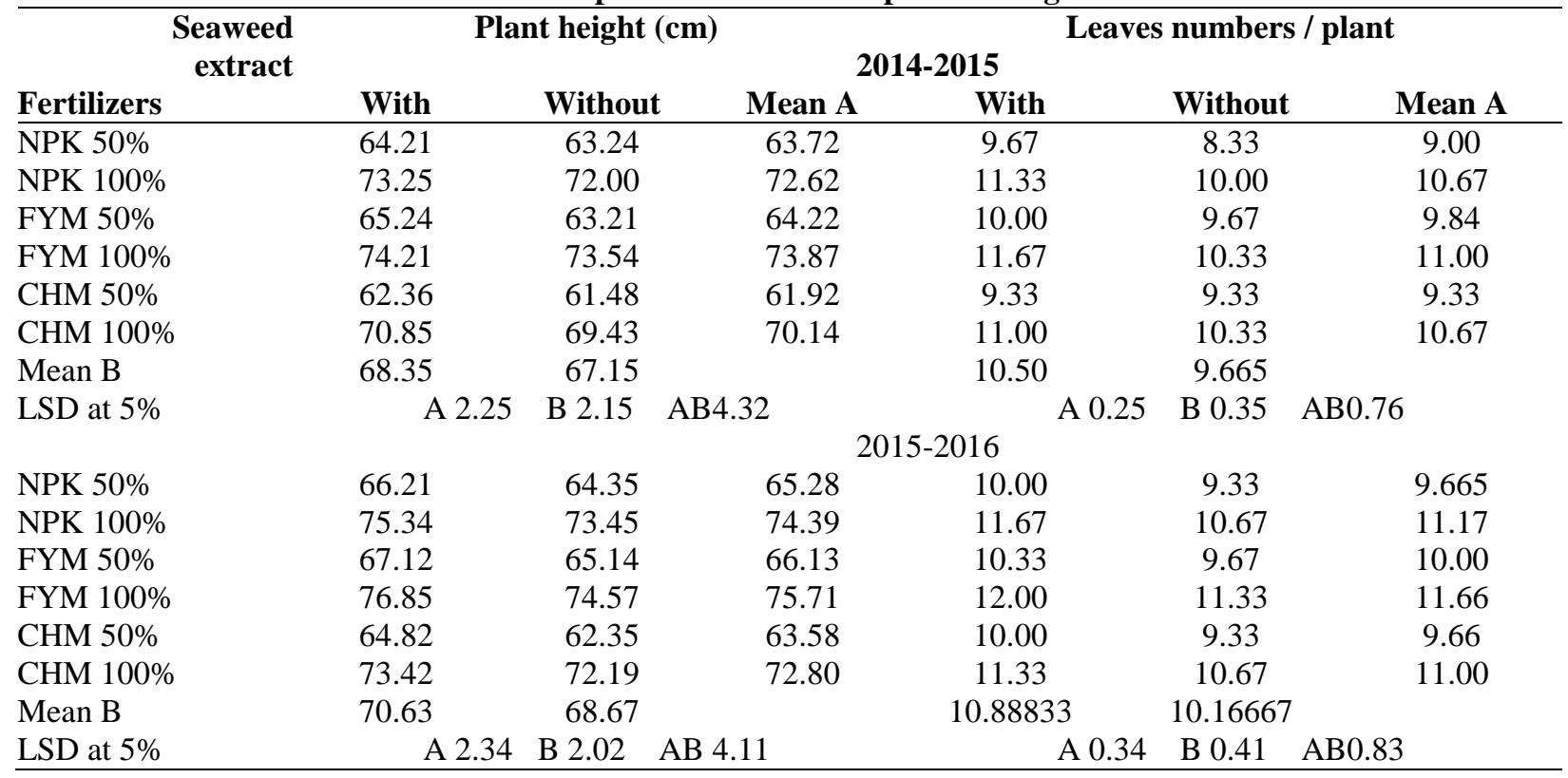

The interaction between seaweed extract and organic manure fertilizers sources or NPK fertilizer had a positive effect on plant height and number of leaves / plant of sweet fennel is presented in (Table 1) in both seasons. Data indicated that the plants fertilized with farmyard manure at $100 \%$ and sprayed with seaweed extract gave the highest values. On the other hand, the lowest values of plant height and number of leaves per plant were reported when the plants received $50 \%$ of chicken manure without foliar spraying with seaweed extract. The results are in accordance with those reported by El-Afifi et.al.(2009) on squash plant.

\section{2- Bulb dimensions:}

Effect of organic manure and NPK fertilizers, data present in Table (2) reveal that bulb dimensions (thickness, width and length) of sweet fennel plants was enhanced by increasing organic manure and NPK fertilizers from 50 to $100 \%$ in two seasons. Moreover, the highest values of bulb dimensions (thickness, width and length) were obtained from application of farmyard manure at the rate of $100 \%$ / fed compared with other chicken manure or NPK treatments at same rate, in both seasons. These results were in agreement with those obtained by El-Desuki et al. (2001) mentioned that organic manure was increased of bulb diameter in fennel plant.

Also, data in Table (2) indicated clearly that the bulb dimensions (thickness, width and length) of sweet fennel plant were significantly increased by foliar application with seaweed extract compared to without seaweed extract treatment, in the two seasons. Similar results on the stimulatory effects of seaweed extract on other plant were also noticed by Tarek and Hassan (2014) found that the application of seaweed extract on garlic plant significantly improved bulb diameter.

The interaction of organic manure fertilizers with seaweed extract resulted in significant increase in bulb dimensions (thickness, width and length) of sweet fennel plant, in the two seasons, data in Table (2). The interaction of farmyard manure at rate of $100 \%$ with seaweed extract resulted in the highest values of bulb dimensions, compared with NPK fertilizers or chicken 
Eisa, E. A.

manure at all rats with seaweed extract, in two seasons. The better efficiency of organic manures might be due to the fact that organic manures especially FYM would have provided the micronutrients such as $\mathrm{Zn}, \mathrm{Cu}, \mathrm{Fe}$, $\mathrm{Mn}$ and $\mathrm{Mg}$ in an optimum level. Zinc is involved in the biochemical synthesis of most important phytohormone, Indole Acetic Acid through the pathway of conversion of IAA. Iron is involved in chlorophyll synthesis pathway. Copper and Manganese are the important coenzymes for certain respiratory reaction. Magnesium is involved in chlorophyll synthesis which in turn increases the rate of photosynthesis. Application of organic manure thus would have helped in the plant metabolic activity through the supply of such important micronutrients in the early vigorous growth (Anburani and Manivannan, 2002).

Table (2): Effect of some different sources of organic fertilizer and seaweed extract on bulb dimensions of sweet fennel plant during 2014-2015 and 2015-2016 seasons.

\begin{tabular}{|c|c|c|}
\hline $\begin{array}{r}\text { Seaweed } \\
\text { extract }\end{array}$ & Bulb thickness & $\begin{array}{r}\text { Bulb width } \\
2014-2015\end{array}$ \\
\hline
\end{tabular}

\begin{tabular}{|c|c|c|c|c|c|c|c|c|c|}
\hline Fertilizers & With & Without & Mean A & With & Without & Mean A & With & Without & Mean A \\
\hline NPK 50\% & 6.74 & 6.24 & 6.49 & 11.64 & 11.24 & 11.44 & 10.54 & 9.57 & 10.05 \\
\hline NPK $100 \%$ & 7.12 & 6.75 & 6.93 & 11.83 & 11.59 & 11.71 & 10.76 & 9.84 & 10.3 \\
\hline FYM 50\% & 6.81 & 6.35 & 6.58 & 11.71 & 11.53 & 11.62 & 10.75 & 6.67 & 8.71 \\
\hline FYM $100 \%$ & 7.23 & 7.05 & 7.14 & 12.00 & 11.84 & 11.92 & 11.02 & 10.10 & 10.56 \\
\hline CHM 50\% & 6.35 & 6.14 & 6.24 & 11.54 & 11.43 & 11.48 & 10.41 & 9.43 & 9.92 \\
\hline CHM $100 \%$ & 6.95 & 6.60 & 6.77 & 11.62 & 11.56 & 11.59 & 10.68 & 9.72 & 10.2 \\
\hline Mean B & 6.87 & 6.52 & & 11.72 & 11.53 & & 10.69 & 9.23 & \\
\hline LSD at5\% & \multicolumn{3}{|c|}{ A 0.23 B 0.15 AB 0.33} & \multicolumn{3}{|c|}{$\begin{array}{l}\text { A } 0.15 \text { B } 0.18 \text { A } \times \text { B } 0.37 \\
2015-2016\end{array}$} & \multicolumn{3}{|c|}{ A 0.30 B $0.31 \mathrm{~A} \times \mathrm{B} 0.63$} \\
\hline NPK 50\% & 6.91 & 6.53 & 6.72 & 11.87 & 11.65 & 11.76 & 10.73 & 9.76 & 10.24 \\
\hline NPK $100 \%$ & 7.06 & 6.91 & 6.98 & 12.01 & 11.83 & 11.92 & 10.96 & 9.98 & 10.47 \\
\hline FYM 50\% & 6.97 & 6.84 & 6.90 & 11.94 & 11.71 & 11.82 & 10.94 & 9.85 & 10.39 \\
\hline FYM $100 \%$ & 7.18 & 7.01 & 7.09 & 12.19 & 11.98 & 12.08 & 11.19 & 10.29 & 10.74 \\
\hline CHM 50\% & 6.74 & 6.53 & 6.63 & 11.72 & 11.56 & 11.64 & 10.59 & 9.65 & 10.12 \\
\hline CHM $100 \%$ & 7.00 & 6.87 & 6.93 & 11.93 & 11.71 & 11.82 & 10.87 & 9.90 & 10.38 \\
\hline Mean B & 6.98 & 6.78 & & 11.94 & 11.74 & & 10.88 & 9.90 & \\
\hline LSD at5\% & \multicolumn{3}{|c|}{ A 0.24 B 0.17 AB 0.35} & \multicolumn{3}{|c|}{ A 0.24 B $0.18 \mathrm{~A} \times \mathrm{B} 0.37$} & \multicolumn{3}{|c|}{ A 0.29 B $0.32 \mathrm{~A} \times \mathrm{B} 0.61$} \\
\hline
\end{tabular}

3- Fresh and dry weight of leaves, bulb and total plant:

Data presented in Table (3 and 4) show that fresh and dry weight of leaves, bulb and total plant of sweet fennel increased with increasing the rates of NPK fertilizers or organic manure treatments, in both seasons. The highest significantly values of fresh and dry weight of leaves, bulb and total plant by treatment receiving farmyard manure at the rate of $100 \%$ followed by NPK fertilizer at the same rate and the least values were resulted from chicken manure treatments, in the two seasons. Positive effect on fresh and dry weight of leaves, bulb and total plant by using organic manure may be attributed to that organic manure enhanced soil aggregation, soil aeration, water holding capacity and offered good soil conditions for the root system of plants (Abou El- Magd et al., 2006). In addition, organic manures are slow releaser and provide nutrients throughout growth period (Arisha et al., 2003). In a field experiment, El-Desuki et al. (2001) found that the average values of fresh and dry weights of leaves and bulb in sweet fennel treated with organic were significant increased compared to control.

Data illustrated in Table (3 and 4) indicated that fresh and dry weight of leaves, bulb and total plant of sweet fennel were significantly increased by foliar spray with seaweed extract treatment compared to without seaweed extract, in both seasons. The stimulating effect of seaweed extract on growth characters might be attributed to its essential action on enhancing cell division because it contains higher amounts of nutrients namely (N,P, K, Mg, Ca, S, Cu, Fe, Mn, B and Mo), natural hormones like cytokines, IA A and GA3, amino acids, vitamins and antioxidants (Soliman et al., 2000), these constituents play an important roles in protecting plants cells from damage and all stresses around plants and improving cell division and the biosynthesis of organic foods (Stirk and Van, 1997). These results are in agreement with those obtained by Abdel Mawgoud et al.(2010) on watermelon and Shehata et al, (2011) on celeriac plant.

As for the interaction effect of the two study factor, data in Table (3 and 4) reveal that fresh and dry weight of leaves, bulb and total plant of sweet fennel influenced by the interaction in both seasons. Generally, fertilized plant with farmyard manure at $100 \%$ combination with seaweed extract produced the highest fresh and dry weight of leaves, bulb and total plant, in two seasons, whereas the lowest values were obtained as a result of untreated by chicken manure without seaweed extract, in both seasons. These results are similar with those reported by El.Afify et al. (2009) on squash plant. 
Table (3): Effect of some different sources of organic fertilizer and seaweed extract on fresh weight (leaves and bulb) of sweet fennel plant during 2014-2015 and 2015-2016 seasons.

\begin{tabular}{|c|c|c|c|c|c|c|c|c|c|}
\hline \multirow[b]{2}{*}{ Fertilizers } & \multicolumn{3}{|c|}{ Leaves (g/plant) } & \multicolumn{3}{|c|}{$\begin{array}{c}\text { Bulb (g/plant) } \\
2014-2015\end{array}$} & \multicolumn{3}{|c|}{ Total (g/plant) } \\
\hline & With & Without & Mean A & With & Without & Mean A & With & Without & Mean A \\
\hline NPK 50\% & 524.2 & 505.4 & 514.8 & 385.2 & 353.6 & 369.4 & 909.4 & 859.0 & 884.2 \\
\hline NPK $100 \%$ & 543.5 & 519.6 & 531.5 & 400.1 & 371.8 & 385.9 & 943.6 & 891.4 & 917.5 \\
\hline FYM 50\% & 531.5 & 511.4 & 521.4 & 394.4 & 365.4 & 379.9 & 925.9 & 876.8 & 901.3 \\
\hline FYM $100 \%$ & 557.3 & 536.3 & 546.8 & 413.5 & 380.4 & 396.9 & 970.8 & 916.7 & 943.7 \\
\hline CHM 50\% & 512.4 & 488.6 & 500.5 & 372.4 & 348.5 & 360.4 & 884.8 & 837.1 & 860.9 \\
\hline CHM $100 \%$ & 531.7 & 518.7 & 525.2 & 393.7 & 360.5 & 377.1 & 925.4 & 879.2 & 902.3 \\
\hline Mean B & 533.4 & 513.3 & & 393.2 & 363.4 & & 926.6 & 876.7 & \\
\hline LSDat5\% & \multicolumn{3}{|c|}{ A 14.3 B 8.4 A×B16.7 } & \multicolumn{3}{|c|}{$6.1 \quad \mathrm{~A} \times \mathrm{B} 12.3$} & \multicolumn{3}{|c|}{ A 16.3 B 10.5 AB20.1 } \\
\hline NPK $50 \%$ & 535.3 & 516.7 & 526.0 & 396.2 & 361.6 & 378.9 & 931.5 & 878.3 & 904.9 \\
\hline NPK $100 \%$ & 556.4 & 530.5 & 543.4 & 414.1 & 373.8 & 393.9 & 970.5 & 904.3 & 937.4 \\
\hline FYM 50\% & 548.7 & 525.2 & 536.9 & 400.4 & 367.4 & 383.9 & 949.1 & 892.6 & 920.8 \\
\hline FYM $100 \%$ & 577.3 & 548.6 & 562.9 & 422.5 & 385.4 & 404.9 & 999.8 & 943.0 & 971.4 \\
\hline CHM 50\% & 523.5 & 505.1 & 514.3 & 383.4 & 360.5 & 371.9 & 906.9 & 865.6 & 886.2 \\
\hline CHM $100 \%$ & 544.3 & 530.3 & 537.3 & 412.7 & 374.5 & 393.6 & 957.0 & 904.8 & 930.9 \\
\hline Mean B & 547.6 & 526.1 & & 404.9 & 373.0 & & 952.5 & 899.1 & \\
\hline LSD at5\% & \multicolumn{3}{|c|}{ A 16.2 B 7.5 AB 15.1} & A 7.2 & B $6.4 \mathrm{~A} \times \mathrm{B}$ & B12.9. & \multicolumn{3}{|c|}{ A 11.4 B 8.5 AB 16.9} \\
\hline
\end{tabular}

Table (4): Effect of some different sources of organic fertilizer and seaweed extract on dry weight (leaves and bulb) of sweet fennel plant during 2014-2015 and 2015-2016 seasons.

\begin{tabular}{|c|c|c|c|c|c|c|c|c|c|}
\hline \multirow[b]{2}{*}{ Fertilizers } & \multicolumn{3}{|c|}{ Leaves (g/plant) } & \multicolumn{3}{|c|}{$\begin{array}{c}\text { Bulb (g/plant) } \\
\text { 2014-2015 }\end{array}$} & \multicolumn{3}{|c|}{ Total (g/plant) } \\
\hline & With & Without & Mean A & With & Without & Mean A & With & Without & Mean A \\
\hline NPK 50\% & 62.98 & 55.54 & 59.26 & 46.51 & 38.84 & 42.67 & 109.5 & 94.38 & 101.9 \\
\hline NPK $100 \%$ & 65.27 & 57.16 & 61.21 & 48.38 & 40.73 & 44.55 & 113.6 & 97.89 & 105.7 \\
\hline FYM 50\% & 63.87 & 56.22 & 60.04 & 47.02 & 40.12 & 43.57 & 110.9 & 96.34 & 103.6 \\
\hline FYM $100 \%$ & 66.52 & 58.94 & 62.73 & 49.75 & 41.79 & 45.77 & 116.3 & 100.7 & 108.5 \\
\hline CHM 50\% & 61.48 & 53.84 & 57.66 & 44.59 & 37.37 & 40.98 & 106.1 & 91.21 & 98.6 \\
\hline CHM 100\% & 63.81 & 56.97 & 60.39 & 42.28 & 39.54 & 40.91 & 106.1 & 96.51 & 101.3 \\
\hline Mean B & 63.99 & 56.44 & & 46.42 & 39.73 & & 110.4 & 96.17 & \\
\hline LSD at5\% & \multicolumn{3}{|c|}{ A 1.2 B 2.5 AB 4.9} & $\begin{array}{r}\text { A } 0.9 \\
2015-2016\end{array}$ & \multicolumn{2}{|c|}{ B 1.3 AB2.5 } & \multicolumn{3}{|c|}{ A 1.6 B 2.4 AB5.0 } \\
\hline NPK 50\% & 64.23 & 56.82 & 60.52 & 47.52 & 39.91 & 43.71 & 111.7 & 96.73 & 104.2 \\
\hline NPK $100 \%$ & 66.75 & 58.82 & 62.78 & $49 . .68$ & 41.25 & 41.25 & 116.4 & 100.07 & 108.2 \\
\hline FYM 50\% & 65.81 & 57.81 & 61.81 & 46.24 & 40.46 & 43.35 & 112.0 & 98.27 & 105.1 \\
\hline FYM $100 \%$ & 69.35 & 60.36 & 64.85 & 50.73 & 43.98 & 47.35 & 120.1 & 104.34 & 112.2 \\
\hline CHM 50\% & 62.94 & 55.71 & 59.32 & 45.90 & 39.87 & 42.88 & 108.8 & 95.58 & 102.2 \\
\hline CHM $100 \%$ & 65.58 & 58.32 & 61.95 & 49.58 & 41.24 & 45.41 & 115.2 & 99.56 & 107.4 \\
\hline Mean B & 65.78 & 57.97 & & 47.99 & 41.11 & & 114.0 & 99.09 & \\
\hline LSD at5\% & A 1.4 & 4 B 1.9 A & AB 3.7 & A 1.0 & B $2.4 \mathrm{AB}$ & 4.9. & A 3.4 & B $3.5 \mathrm{~A}$ & В 6.9 \\
\hline
\end{tabular}

II-Effect of mineral, organic fertilizers and seaweed extract on fruit stage:

1- Number of umbels / plant and fruit yield (g/plant): Data shown in Table (5) pointed out significant differences in number of umbels and fruit yield per plant as affected by the mineral and different organic fertilizers in both seasons. The plants that received the farmyard manure at $100 \%$ had the largest number of umbels and fruit yield per plant; however the least number of umbels and fruit yield per plant were formed on the plants supplied with the low rate of chicken manure in the first and second seasons. These results were in line with those of Dadiga et al. (2015) on coriander plant
It was clear from data in Table (5) that seaweed extract increased number of umbels and fruit yield per plant significantly when compared with the control (without seaweed extract) in both seasons. The synergistic effect of seaweed extract may be due to the increase on plant growth. These results were in accordance to those obtained by Gehan (2015) on fennel plant.

It can be observed from data in Table (5) that in the two seasons, the plants that received the farmyard manure and sprayed with seaweed extract formed the largest number of umbels and fruit yield per plant, however the plants that received the chicken manure without seaweed extract formed the least number of 
umbels and fruit yield per plant. The differences between most interaction treatments were significant in both seasons. The positive effect of farmyard manure on number of umbels and fruit yield per plant might be related to the improvement of physical conditions of the soil, which provided energy for micro-organisms' activity and increased the availability and uptake of nutrients, which were positively reflected on the increase plant growth, number of umbels and fruit yield per plant. Higher yield response due to organics is ascribed to improvement in physical and biological properties of soil resulted in better supply of nutrients led to good crop growth and yield. The reason for increased number of umbels and fruit yield could be attributed to solubilization effect of plant nutrients by the addition of FYM leading to increased uptake of NPK (Sendurkumaran et al., 1998).

Table (5): Effect of some different sources of organic fertilizer and seaweed extract on number of umbels / plant and fruit yield (g/plant) of sweet fennel plant during 2014-2015 and 2015-2016 seasons.

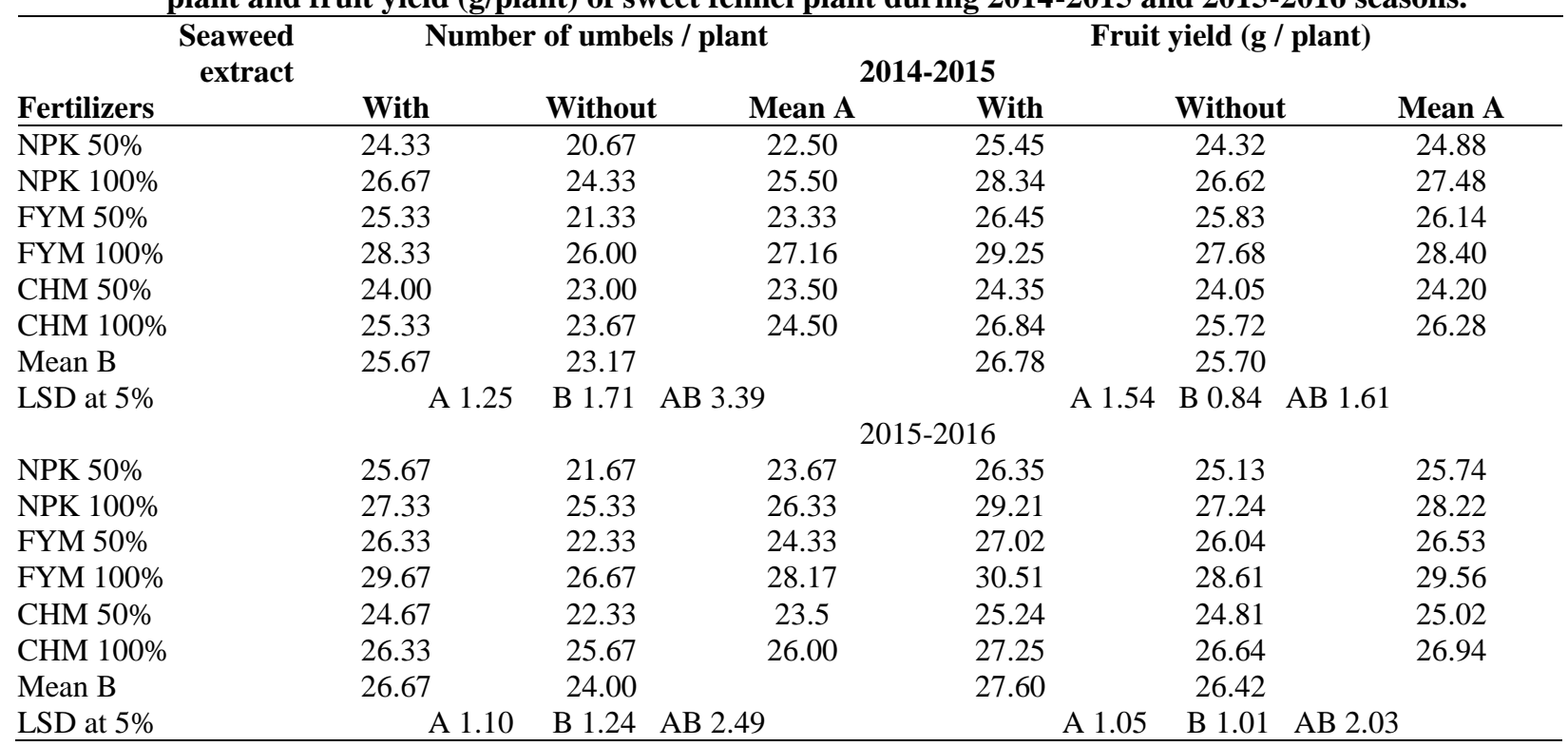

2- Yield of bulb and fruit /fed.:

The obtained data in Table (6) showed significant differences between mineral and organic fertilizers at $100 \%$ when compared with mineral and organic fertilizers at $50 \%$ in both seasons. The plants which received the farmyard manure at $100 \%$ recorded the heaviest bulbs and fruit yield per fed., while the plants that received the lowest chicken manure dose recorded the lightest bulbs and fruit yield per fed. In both seasons. The promotive effect of farmyard manure may be due to increase of nutrients in the soil. This increase can encourage the plant growth, which increased the photosynthetic rates leading to an increase in the assimilation rates and hence the bulbs and fruit yield per feddan were increased. The above mentioned results followed the same trend of these obtained by Zeinab et al. (2015) on sweet fennel plants and Dadiga et al. (2015) on coriander plant.

Table (6): Effect of some different sources of organic fertilizer and seaweed extract on yield of bulbs and fruit /fed. of sweet fennel plant during 2014-2015 and 2015-2016 seasons.

\begin{tabular}{|c|c|c|c|c|c|c|c|}
\hline \multirow[b]{3}{*}{ Fertilizers } & \multicolumn{3}{|c|}{ Bulb yield (ton/fed. ) } & \multicolumn{4}{|c|}{ Fruit yield (kg/fed. ) } \\
\hline & \multirow[b]{2}{*}{ With } & \multirow[b]{2}{*}{ Without } & \multirow{2}{*}{ Mean A } & 2014-2015 & & \multirow[b]{2}{*}{ Without } & \multirow[b]{2}{*}{ Mean A } \\
\hline & & & & With & & & \\
\hline NPK 50\% & 10.272 & 9.429 & 9.850 & 678.6 & & 648.5 & 663.6 \\
\hline NPK $100 \%$ & 10.670 & 9.914 & 10.292 & 755.7 & & 709.8 & 732.8 \\
\hline FYM 50\% & 10.517 & 9.744 & 10.130 & 705.3 & & 688.8 & 697.1 \\
\hline FYM $100 \%$ & 11.026 & 10.144 & 10.585 & 780.0 & & 738.1 & 759.1 \\
\hline CHM 50\% & 9.930 & 9.293 & 9.6115 & 649.3 & & 641.3 & 645.3 \\
\hline CHM $100 \%$ & 10.498 & 9.613 & 10.055 & 715.7 & & 710.4 & 713.1 \\
\hline Mean B & 10.4855 & 9.6895 & & 714.1 & & 689.4 & \\
\hline \multirow[t]{2}{*}{$\mathrm{LSD}$ at $5 \%$} & A 0.215 & B 0.321 & $\mathrm{AB} 0.642$ & & A 14.3 & B 11.5 & AB 22.9 \\
\hline & \multicolumn{7}{|c|}{ 2015-2016 } \\
\hline NPK $50 \%$ & 10.565 & 9.642 & 10.103 & 702.6 & & 670.1 & 686.3 \\
\hline NPK $100 \%$ & 11.420 & 9.968 & 10.694 & 778.9 & & 726.4 & 752.6 \\
\hline FYM $50 \%$ & 10.677 & 9.797 & 10.237 & 720.5 & & 694.4 & 707.4 \\
\hline FYM $100 \%$ & 11.266 & 10.277 & 10.771 & 813.6 & & 762.9 & 788.2 \\
\hline CHM 50\% & 10.224 & 9.613 & 9.918 & 673.0 & & 661.6 & 667.3 \\
\hline CHM $100 \%$ & 11.005 & 9.960 & 10.482 & 726.6 & & 710.4 & 718.5 \\
\hline Mean B & 10.859 & 9.876 & & 735.9 & & 704.3 & \\
\hline LSD at $5 \%$ & A 0.184 & B 0.268 & $\mathrm{AB} \quad 0.539$ & & A 16.1 & B 14.2 & AB 28.5 \\
\hline
\end{tabular}


Data shown in Table (6) point out significant increase in bulbs and fruit yield per fed. as affected by the seaweed extract when compared to without seaweed extract, in both seasons. Also, yield increases in seaweed-treated plants are thought to be associated with the hormonal substances present in the extracts especially cytokinins (Norrie and Keathley, 2005).

These results confirmed with the finding of Gehan (2015) on fennel plant. Also, Dogra and Mandradia (2012) mentioned that Seaweed extract was the best in enhancing bulb weight and yield in onion plant.

The data in Table (6) showed variable differences in bulbs and fruit yield per fed., in the two seasons. The plants which received the mineral or organic fertilizers and sprayed with seaweed extract increased significant with compared by plants which received the mineral or organic fertilizers and without seaweed extract. Fertilized plant with farmyard manure at $100 \%$ and sprayed by seaweed extract gave the highest value followed by plants received the NPK fertilizer and sprayed also with seaweed extract. On the other hand, plants that received the low chicken manure dose without seaweed extract gave the lowest value.

\section{III- Essential oil determination:}

The collected data in Table (7), cleared that the percentage, content per plant $(\mathrm{ml})$ and yield per feddan (liter) of essential oil were affected with different sources and rates of organic manure, comparative with NPK fertilizer, in both seasons. The highest values resulted from plants fertilized with the farmyard manure, followed by NPK fertilizer, while the lowest essential oil percentage, oil content / plant and oil yield / fed., resulted from plants fertilized with the chicken manure. The favourable effect of the farmyard manure may be due to its effect on number of umbels per plant and fruit yield/fed., hence the oil content / plant and oil yield / fed., were increased. The above mentioned results followed the same trend of these obtained by Younesian et al. (2013) on sweet fennel plant.

Table (7): Effect of some different sources of organic fertilizer and seaweed extract on percentage, content per plant $(\mathrm{ml})$ and yield per feddan (liter) of essential oil of sweet fennel plant during 2014-2015 and 2015-2016 seasons.

\begin{tabular}{|c|c|c|c|c|c|c|c|c|c|}
\hline \multirow[b]{2}{*}{ fertilizers } & \multicolumn{3}{|c|}{ Essential oil percentage } & \multicolumn{3}{|c|}{$\begin{array}{c}\text { Essential oil content/plant } \\
2014-2015\end{array}$} & \multicolumn{3}{|c|}{ Essential oil yield/fed. } \\
\hline & With & Withou & Mean A & With & Without & Mean A & With & Without & Mean A \\
\hline NPK 50\% & 1.12 & 1.08 & 1.10 & 0.285 & 0.262 & 0.273 & 7.599 & 6.986 & 7.292 \\
\hline NPK $100 \%$ & 1.13 & 1.10 & 1.11 & 0.320 & 0.293 & 0.306 & 8.533 & 7.813 & 8.173 \\
\hline FYM 50\% & 1.12 & 1.09 & 1.10 & 0.296 & 0.282 & 0.289 & 7.893 & 7.519 & 7.706 \\
\hline FYM $100 \%$ & 1.14 & 1.11 & 1.12 & 0.333 & 0.307 & 0.320 & 8.879 & 8.186 & 8.532 \\
\hline CHM 50\% & 1.11 & 1.07 & 1.09 & 0.270 & 0.257 & 0.263 & 7.199 & 6.853 & 7.026 \\
\hline CHM $100 \%$ & 1.12 & 1.09 & 1.10 & 0.301 & 0.280 & 0.290 & 8.026 & 7.466 & 7.746 \\
\hline Mean B & 1.12 & 1.09 & & 0.301 & 0.280 & & 8.021 & 7.470 & \\
\hline LSD at $5 \%$ & A 0.01 & B 0.01 & $\mathrm{AB} 0.02$ & $\begin{array}{r}\text { A } 0.04 \\
2015-201\end{array}$ & $\begin{array}{l}\text { B } 0.03 \text { A } \\
6\end{array}$ & В 0.07 & A 0.52 & В 0.33 & $\mathrm{AB} 0.65$ \\
\hline NPK 50\% & 1.14 & 1.08 & 1.11 & 0.300 & 0.271 & 0.285 & 8.026 & 7.226 & 7.626 \\
\hline NPK $100 \%$ & 1.16 & 1.10 & 1.13 & 0.304 & 0.299 & 0.301 & 8.106 & 7.973 & 8.039 \\
\hline FYM 50\% & 1.15 & 1.13 & 1.14 & 0.311 & 0.294 & 0.302 & 8.293 & 7.839 & 8.066 \\
\hline FYM $100 \%$ & 1.18 & 1.15 & 1.16 & 0.360 & 0.329 & 0.344 & 9.599 & 8.773 & 9.186 \\
\hline CHM 50\% & 1.12 & 1.08 & 1.10 & 0.283 & 0.268 & 0.275 & 7.456 & 7.146 & 7.301 \\
\hline CHM $100 \%$ & 1.13 & 1.10 & 1.11 & 0.308 & 0.293 & 0.300 & 8.213 & 7.813 & 8.013 \\
\hline Mean B & 1.15 & 1.11 & & 0.311 & 0.292 & & 8.282 & 7.795 & \\
\hline LSD at $5 \%$ & A 0.01 & $1 \mathrm{~B} 0.01$ & AB 0.02 & A 0.03 & B $0.04 \mathrm{~A}$ & B 0.07 & A 0.48 & В 0.29 & $\mathrm{AB} 0.60$ \\
\hline
\end{tabular}

Data in Table (7) revealed that the percentage, content per plant $(\mathrm{ml})$ and yield per feddan (liter) of essential oil were significantly affected by the plant sprayed with seaweed extract with compared to without seaweed extract during the two growing seasons. These results confirmed with the finding of Gehan (2015) on fennel plant.

It was clear from the data presented in Table (7) that a significant interaction effect was observed between mineral or organic fertilizers and seaweed extract treatments on essential oil percentage, oil content $\mathrm{ml} /$ plant and oil yield liter / feddan in both seasons. The plants supplied with the farmyard manure at $100 \%$ and sprayed with seaweed extract recorded the highest value, followed by mineral fertilizer at $100 \%$ with seaweed extract, while the least value resulted from plants supplied with the low chicken manure dose without seaweed extract.

\section{IV-Chemical constituents:}

\section{1-Chlorophyll a+b content and total carbohydrates percentages:}

Data presented in Table (8) indicated in the two seasons that fertilizing plants with the farmyard manure at $100 \%$ produced the highest chlorophyll $\mathrm{a}+\mathrm{b}$ content in fresh leaves and total carbohydrates percentages in dried leaves of sweet fennel plant, followed by NPK at $100 \%$, while fertilizing plants with the low chicken manure dose gave the lowest values in this concern. The favourable effect of the full suitable farmyard manure 
on chlorophyll $\mathrm{a}+\mathrm{b}$ content and total carbohydrate percentages may infer that farmyard manure enabled plants to absorb efficiently water and available nutrients from soil, leading to growth, encourage photosynthetic activity and accumulation of carbohydrates. These findings agreed with the work of El-Afifi et al (2009) on squash plants.

Data in the same Table revealed that, the chlorophyll $\mathrm{a}+\mathrm{b}$ content in fresh leaves and total carbohydrates percentage in dried leaves of sweet fennel plant were significantly affected by the plant sprayed with seaweed extract when compared to without seaweed extract during the two growing seasons. The higher own content of seaweed extract from nutrients especially $(\mathrm{Mg})$ as well as amino acids and vitamins surely reflected on enhancing the biosynthesis of plant pigments and total carbohydrates consequently advancing carbohydrate maturity (Soliman et. al., 2000) Moreover, these results were in agreement with the results obtained by Shehata et al. (2011) on celeriac plant

Table (8): Effect of some different sources of organic fertilizer and seaweed extract on chlorophyll a+b content in fresh leaves and total carbohydrates percentages in dried leaves of sweet fennel plant during 2014-2015 and 2015-2016 seasons.

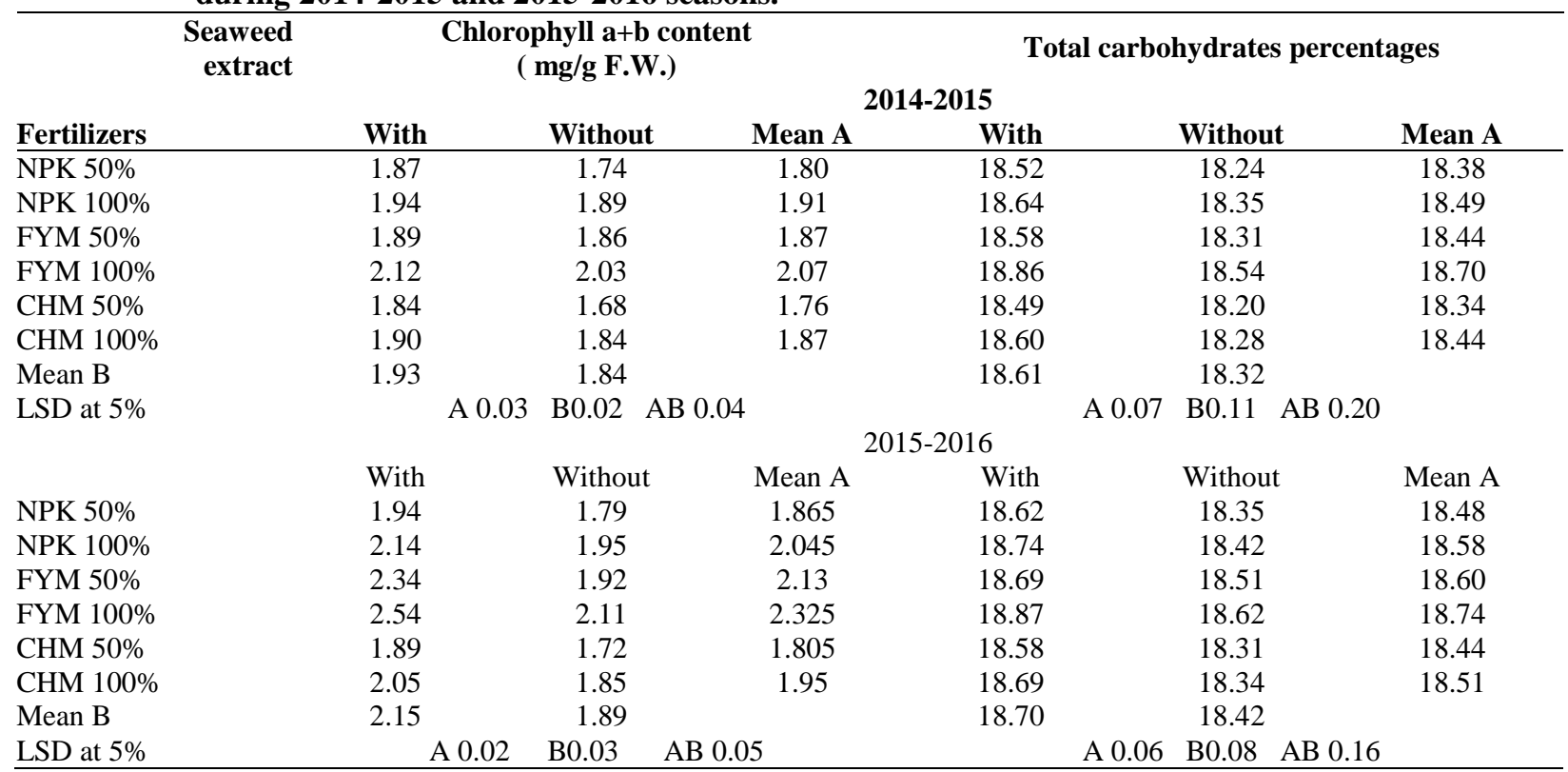

Concerning the interaction effect between mineral or organic fertilizers and seaweed extract treatments (Table, 8), it was noticed that plants which received the farmyard manure at $100 \%$ and sprayed with seaweed extract recorded the highest chlorophyll $a+b$ content in fresh leaves and total carbohydrates percentage in dried leaves of sweet fennel plant, while fertilizing plants with the chicken manure gave the lowest values in this concern. The chlorophyll content in the leaves might have been significantly improved with the application of organic source of nutrients. The increased application of FYM, which contain appreciable quantities of magnesium, might have helped in chlorophyll synthesis which in turn increased the rate of photosynthesis. The results are in agreement with the findings of and Sanwal et al. (2007). These results are in agreement with those obtained by El-Afifi et al.(2009) on squash plants

\section{2. $N, P$ and $K$ percentages:}

Mineral and organic fertilizers induced variable $\mathrm{N}, \mathrm{P}$ and $\mathrm{K}$ percentages in both seasons as presented in Table (9). The high mineral and organic fertilizers gave considerably the highest nitrogen, phosphorus and potassium in the both seasons. As well as, the farmyard manure gave the highest values of $\mathrm{N}$ and $\mathrm{P}$ percentage, while the chicken manure led to the highest potassium percentage, in the two seasons. These results were in agreement with the findings of El-Afifi et al.(2009) on squash plants.

Data in Table (9) clearly illustrate that the folair application of seaweed extract significantly affected percentages of $\mathrm{N}, \mathrm{P}$ and $\mathrm{K}$ in leaves of sweet fennel plant. The highest respect values of macronutrients $(\mathrm{N}$, $\mathrm{P}$ and $\mathrm{K}$ ) were obtained from the plant which were foliar sprayed by seaweed extract in the two seasons. The increments of $\mathrm{N}, \mathrm{P}$ and $\mathrm{K}$ percentage in the leaves might be attributed to organic and mineral elements constituents of seaweed extract. This trend is similar to that of Shehata et al. (2011) on celeriac plant

It was quite clear from results in Table (9) that the nitrogen, phosphorus and potassium percentages of sweet fennel herb were affected by the interaction between mineral or organic fertilizers and seaweed extract. The high farmyard manure dose combined with seaweed extract gave the highest percentages of $\mathrm{N}$ and $\mathrm{P}$, while the chicken manure at $100 \%$ combined with seaweed extract gave the highest percentages of $\mathrm{P}$ in the two seasons, respectively. These results were in agreement with those obtained by El-Afifi et al. (2009) on squash plants. 
Table (9): Effect of some different sources of organic fertilizer and seaweed extract on $\mathbf{N}, \mathbf{P}$ and $\mathrm{K}$ percentages / dried herb of sweet fennel plant during 2014-2015 and 2015-2016 seasons.

\begin{tabular}{|c|c|c|c|c|c|c|c|c|c|}
\hline \multicolumn{2}{|c|}{$\begin{array}{r}\text { Seaweed } \\
\text { extract }\end{array}$} & \multicolumn{2}{|l|}{$\mathbf{N}(\%)$} & \multicolumn{3}{|c|}{$\begin{array}{c}P(\%) \\
2014-2015\end{array}$} & \multicolumn{3}{|c|}{$\mathbf{K}(\%)$} \\
\hline Fertilizers & With & Without & Mean A & With & Without & Mean A & With & Without & Mean A \\
\hline NPK 50\% & 1.57 & 1.53 & 1.55 & 0.42 & 0.40 & 0.41 & 2.42 & 2.34 & 2.38 \\
\hline NPK $100 \%$ & 1.86 & 1.79 & 1.82 & 0.44 & 0.41 & 0.42 & 2.54 & 2.51 & 2.52 \\
\hline FYM 50\% & 167 & 1.56 & 1.56 & 0.42 & 0.41 & 0.42 & 2.51 & 2.47 & 2.49 \\
\hline FYM $100 \%$ & 1.93 & 1.80 & 1.86 & 0.47 & 0.45 & 0.46 & 2.58 & 2.53 & 2.55 \\
\hline CHM 50\% & 1.56 & 1.47 & 1.51 & 0.41 & 0.40 & 0.40 & 2.64 & 2.55 & 2.59 \\
\hline CHM $100 \%$ & 1.67 & 1.53 & 1.60 & 0.42 & 0.41 & 0.43 & 2.59 & 2.58 & 2.58 \\
\hline Mean B & 1.72 & 1.61 & & 0.43 & 0.41 & & 2.55 & 2.50 & \\
\hline LSD at $5 \%$ & \multicolumn{3}{|c|}{ A 0.03 B $0.02 \mathrm{AB} 0.05$} & \multicolumn{3}{|c|}{$\begin{array}{l}\text { A } 0.02 \text { B } 0.01 \text { AB } 0.02 \\
2015-2016\end{array}$} & \multicolumn{3}{|c|}{ A 0.03 B 0.02 AB 0.04} \\
\hline NPK 50\% & 1.64 & 1.60 & 1.62 & 0.45 & 0.40 & 0.42 & 2.34 & 2.28 & 2.31 \\
\hline NPK $100 \%$ & 1.89 & 1.81 & 1.85 & 0.54 & 0.51 & 0.52 & 2.49 & 2.36 & 2.42 \\
\hline FYM 50\% & 1.76 & 1.72 & 1.74 & 0.49 & 0.47 & 0.48 & 2.45 & 2.41 & 2.43 \\
\hline FYM 100\% & 1.92 & 1.90 & 1.91 & 0.51 & 0.50 & 0.50 & 2.49 & 2.42 & 2.45 \\
\hline CHM 50\% & 1.59 & 1.50 & 1.54 & 0.50 & 0.49 & 0.49 & 2.58 & 2.54 & 2.56 \\
\hline CHM $100 \%$ & 1.67 & 1.61 & 1.64 & 0.54 & 0.50 & 0.52 & 2.59 & 2.55 & 2.57 \\
\hline Mean B & 1.74 & 1.69 & & 0.50 & 0.48 & & 2.49 & 2.43 & \\
\hline LSD at5\% & \multicolumn{3}{|c|}{ A 0.02 B 0.02 AB 0.04} & \multicolumn{3}{|c|}{ A 0.02 B 0.01 AB 0.02} & \multicolumn{3}{|c|}{ A 0.03 B 0. B 03 A 0.06} \\
\hline
\end{tabular}

\section{REFERENES}

Abd-Alla, A. M.; Safia M. Adam, and A. F. AbouHadid (2001).Productivity of green cowpea in sandy soil as influenced by different organic manure rates and sources. Egyptian Journal of Horticulture 28(3): 331-340.

Abdel-Mawgoud, A. M. R., A. S. Tantawy, Magda M . Hafez and Hoda A. M. Habib (2010). Seaweed extract improves growth, yield and quality of different watermelon hybrids Rese. J. of Agric. and Biological Sci., 6(2): 161-186.

Abd El- Wahab, M. A. and H. R. Mehasen, 2009. Effect of Locations and Sowing Date on (FoeniculumVulgare Mill.) Indian Fennel Type under Upper Egypt Conditions. Journal of Applied Sciences Research, 5 (6): 677-685.

Abou El-Magd M.M., A.M. El-Bassiony and Z.F. Fawzy (2006). Effect of organic manure with or without chemical fertilizers on growth, yield and quality of some varieties of Broccoli plants. J. of Applied Scie. Rese. 2(10): 791-798.

Anburani A. and K.Manivannan (2002). Effect of integrated nutrient management on growth in brinjal (Solanum melongena L.) cv. Annamalai. South Indian Hortic. 50(4-6): 377-386.

Arisha, H.M.E., A.A. Gad and S.E. Younes (2003). Response of some pepper cultivars to organic and mineral nitrogen fertilizer under sandy soil conditions. Zagazig J. of Agric. Rese. 30: 1875 99.

A.O.A.C. Association of Official Analytical Chemists (1990) Official methods of analysis 15 thEd. Washington, D.C., USA.

Braun, M. and G. Franz (1990). Quality criteria of bitter fennel oil in the German pharmacopoeia. Pharm PharmcoelLett;; 9 (2): 48-51.
Camargo, J.A. and A.Alonso (2006). Ecological and toxicological effects of inorganic nitrogen pollution in aquatic ecosystems: a global assessment. Environment Intern., 32:831-849.

Cassan L., I. Jeannin, T. Lamaze and JF. MorotGavdry (1992). The effect of the Ascophyllumnodosumextracts Goemar GA 14 on growth of spinach. Botanica Marina. 35(5):437-9.

Crouch IJ, RP. Beckett and J.Van Staden (1990). Effect of seaweed concentrates on the growth and mineral nutrition of nutrient-stressed lettuce. J. of Applied Phycology., 2(3):269-72.

Crouch IJ, and J.Van Staden (1993). Evidence for the presence of plant growth regulators in commercial seaweed products. Plant Growth Regulator. 13(1):21-9.

Dadiga A., S. Kadwey and S. Prajapati (2015). Influences of organic and inorganic sources of nutrients on growth, yield attributed traits and yield economic of coriander (Coriandrum sativum L.) cv JD-1. Indian J. Agric. Res., 49 (6), 577-580.

Dogra BS. and K. Mandradia ( 2012). Effect of seaweed extract on growth and yield of onion.Inter. J. of Farm Sci. 2(1) : 59-64,

El-Afifi, S. T., E.A.A. Tartoura and Sally M. Shaaban, 2009.Effect of some different sourses and rates of organic manure on summer squash yield peoduction. J. Agric. Sci. Mansoura Univ., 34(3): 1757-1780.

Egypt Magazine (2000).www. sis. gov. eg / public /magazine/iss023e/ht ml/mag11.ht m.

ELDesuki, M., A.H. Amer, Omaima, M. Sawan and M.E. Khattab (2001). Effect of irrigation and organic fertilization on the growth, bulb yield and quality of sweet fennel under Shark. ELOwinat conditions J. Agric. Sci. Mansoura univ. 26(7) 4465-4481 
Eisa, E. A.

Gehan G. Mostafa (2015). Improving the Growth of Fennel Plant Grown under Salinity Stress using some Biostimulants Am. J. Plant Physiol., 10 (2): 77-83,

Grieve, A. A.1984. Modern Herbal. New York: Penguin.

Facciola S. (1990). Cornucopia: a sourcebook of edible plants. Kampong Pub.

Fleurence J. (1999) Seaweed protein: biochemical, nutritional aspects and potential uses. Trend Food Sci\&Technol 10: 25-28.

Herbert, D.; P.J. Phipps and R.E. Strange (1971).Determination of total carbohydrates. Method. Microbiol., 5(8): 290-344.

Kavitha MP, V. Ganesaraja and VK. Paulpandi (2008). Effect of foliar spraying of sea weed extract on growth and yield of rice (Oryzasativa L.). Agricultural Sci. Digest.; 28(2):127-9.

Lawrence, B.M. (1984). Progress in essential oils.PerfFlav; 9 (1): 59-60 (1984).

Norrie, J. and J.P. Keathley (2005). Benefits of ascophyllum nodosum marine-plant extract applications to Thompson Seedless grape production. Proceedings of the $5^{\text {th }}$ International Symposium on Plant Bioregulators in Fruit Production, 29-June 2, Leuven, pp: 243-248.

Page A. L.(1982). Methods of Soil Analysis.2nd, Ed., Part 1, Soil Sci. Soc. Amer., Madisc, wic., USA.

Sanni, K. O. (2016). Effect of compost, cow dung and NPK 15-15-15 fertilizer on growth and yield performance of Amaranth (Amaranthus hybridus). Intern. J. of Advances in Scientific Res.; 2(03): 076-082.

Sanwal S.K., K. Lakminarayana, R.K Yadav., N. Rai, D.S. Yadav and B. Mousumi (2007). Effect of organic manures on soil fertility, growth, physiology, yield and quality of turmeric. Indian J. of Hortic. 64(4): 444-449.
Sendurkumaran S., S. Natarajan and S. Thamburaj (1998). Effect of organic and inorganic fertilizers on growth, yield and quality of tomato. South Indian Hortic. 46(3 and 4):203-205.

Shehata , S. M., Heba. S. Abdel-Azem, A. Abou ElYazied and A. M. El-Gizawy (2011). Effect of Foliar Spraying with Amino Acids and Seaweed Extract on Growth Chemical Constitutes, Yield and its Quality of Celeriac Plant. European J. of Scientific Res. Vol.58 No.2, pp.257-265.

Soliman, A.R.I., M.H. Hussien, S.S.A. Dessoui and Y. Torky (2000). Production of phytohormones by some blue green algae used as soil inoculants for rice fields in Egypt. J. Union Arab Biol., Cairo, Physiology and Algae., 88: 83-102.

Snedecor, W. C. and W. G. Cochran (1980). Statistical Methods. 7 th ed., 2 nd printing. The Iowa State Univ. Press, Ames, Iowa, U.S.A.

Stirk WA. and SJ.Van (1997). Screening of some South African seaweed for cytokinin-like activity. S. Afr. Bot, 63, 161-166.

Tarek A. Shalaby and Hassan El-Ramady (2014). Effect of foliar application of bio-stimulants on growth, yield, components, and storability of garlic (Allium sativumL.). Australian, J. Crop Sci. 8(2):271-275.

Wettstein D. (1957). Chlorophyll - letale und der submikroskopische Formwechsel der Plastiden. Exp. Cell Res. 12, 427-487.

Younesian A., S. Taheri and P.R. Moghaddam (2013).The effect of organic and biological fertilizers on essential oil content of Foeniculum vulgare Mill. (Sweet Fennel). Intl J Agri Crop Sci. Vol., 5 (18), 2141-2146.

Zeinab A. Salama, Farouk K. El Baz, Alaa A. Gaafar and Zaki M. F. (2015). Antioxidant activities of phenolics, flavonoids and vitamin $\mathrm{C}$ in two cultivars of fennel (Foeniculum vulgare Mill.) in responses to organic and bio-organic fertilizers. J. of the Saudi Society of Agric. Sci. 14, 91-99.

\section{تأثير بعض مصادر مختلفة من السماد العضوى وخلاصـة الأعثـاب البحريـة على النمو والزيت الطيار فى نبـات الثمر الطلو.

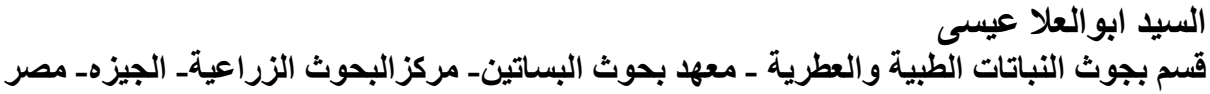

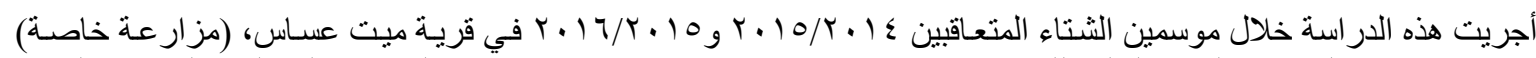

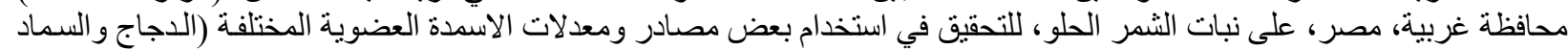

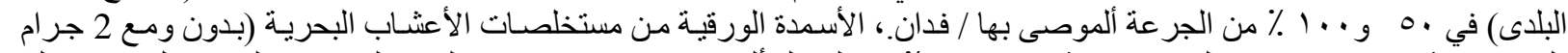

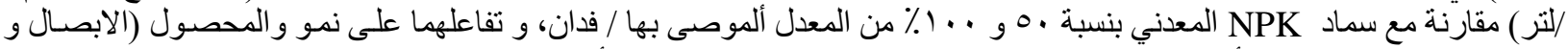

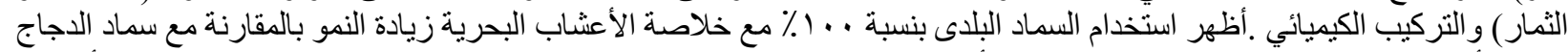

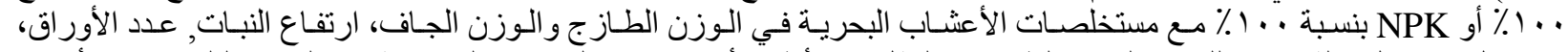

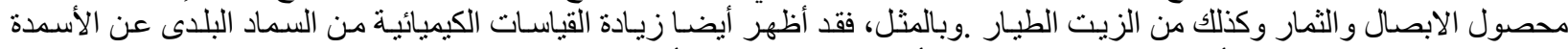

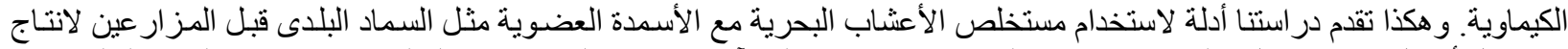

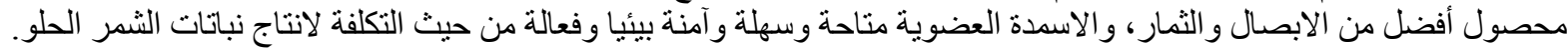

